\title{
A kis játékok kondicionáló szerepe a labdarúgásban
}

\section{Role of Small-sided Games in Football Conditioning}

\section{Papp Károly¹, Szekeres Lajos¹, ifj. Tóth János², Tóth János²}

1 Békéscsabai Labdarúgó Akadémia, Békéscsaba

2 Testnevelési Egyetem, Sportjáték Tanszék, Budapest

Absztrakt: A kis játékokat a kondicionális képességek fejlesztésének a céljából évek óta használják a labdarúgásban. A 3v3 elleni kisjátékot, mint nagy intenzitású állóképességi gyakorlatot (HR max > 90-95\%) használtuk, felnőtt játékosok edzésekor. Hetente két alkalommal, tizennégy héten keresztül edzettek a játékosok ezzel a módszerrel. Az elsó héten $3 \times 3$ percig dolgoztak, a restitúciós idő 2 perc volt. A tizennegyedik hétre a terhelés 8x3 percre emelkedett. Az állóképesség szint felméréséhez a Yoyo Intermittent Recovery Level 2 tesztet használtuk. Az első héten, a teszten a csapat átlaga 1255 méter volt. A tizennegyedik héten pedig 1855 méter. Megállapítható, hogy az alkalmazott edzésmódszerek hatására a játékosok állóképessége jelentősen növekedett.

Kulcsszavak: labdarúgás, kis játékok, álóképesség

Abstract: Small sided games have been used in football for years with the purpose of developing conditional skills. The $3 \mathrm{v} 3$ small sided game, as a high intensity endurance practice was used (HR max $>90-95 \%$ ) in training adult players. The players trained with this method twice a week for 14 weeks. They worked for $3 \times 3$ minutes in week 1 , the recovery time was two minutes. By week 14 , the load was increased to $8 \times 3$ minutes. Yoyo Intermittent Recovery Level 2 was used to assess the endurance level. The average of the team was $1,255 \mathrm{~m}$ in week 1 . It increased to $1,855 \mathrm{~m}$ by week 14 . It can be declared, that with the applied training methods the endurance of the players significantly improved.

Keywords: football, small sided games, endurance

\section{Bevezetés}

A labdarúgás, mint az egyik legnépszerübb sportág, nemcsak népszerü, hanem - talán a népszerüség okán - az egyik legdinamikusabban fejlődő sportág is. A fejlődés megköveteli a módszerek követelmény arányos adekvát alkalmazását is. A kilencvenes évek elejétól beszélhetünk tudatos játék alapú kondicionálásról. Ennek egyik alapja az informatika fejlődése, amely lehetőséget biztosít a játékosok játékteljesítményének objektív értékelésére. A megfigyelések arra engedtek következtetni, hogy a játékosok létszáma párhuzamban a játék területével emeli vagy csökkenti a játékosra nehezedő fizikai igénybevételt.

Ezen elvek alapján az ún. kis játékok alkalmasak a nagy intenzitással végzett állóképességi edzésre, valamint a létszám és a terület növelésével, alacsonyabb intenzitású állóképességi módszerek elvégzésére is. A nagy intenzitású állóképesség alapja az anaerob küszöb felett végzett munka.

A kis játékoknak helyzetfelismerő és megoldó képességet, technikai és taktikai felkészültséget fejlesztő hatása ismert. Mi az állóképességet befolyásoló hatását vizsgáltuk meg.

A kis játékok több edzéscélt is szolgálnak, ebből egyet, az állóképesség fejlesztő hatást elemeztük úgy, hogy nem csak a saját tapasztalatainkat használtuk fel, hanem igyekeztünk összegyűjteni a témához kapcsolódó külföldi szakirodalmat is. Egy szakmai elemzés annál hitelesebb, ha a tanulmány szerzője minél több forrást használ fel. A cikkben a 3v3 elleni játékot elemeztük. 3v3 létszámban edzettek a játékosok 14 héten keresztül. Ennek a 14 hetes munkának a tapasztalatait írtuk le ebben a cikkben.

A játék során jelentkező terhelés mértékét a játékos maximális pulzusának százalékos $\left(\mathrm{HR}_{\max } \%\right)$ 
arányában lehet meghatározni. A nagy intenzitású állóképességi módszer terhelésének meghatározásához Tabata és mtsai (1996) a $\mathrm{HR}_{\text {max }}$ értékét 90\% felett határozták meg. Az anaerob küszöb értéke azonban átlagosan ennél alacsonyabban található. $\mathrm{Ez}$ igen gyakran $\mathrm{HR}_{\max } 85-88 \%$ értéken van. Így sok esetben az ezen a szinten végzett edzés is kifejti azt a hatást, mint a $>\mathrm{HR}_{\max } 90 \%$. Fontos az edzésben részt vevő játékos anaerob küszöb értékének pontos meghatározása. Az így nyert adatok felhasználásával lehet egy reális alapokon nyugvó nagy intenzitású terhelés meghatározása.

A kis játékok felosztása az 1v1 elleni játéktól a 8v8 elleni játékokig terjed. Az azonos létszámmal végzett játékformációkat használja a nemzetközi szakirodalom a kondicionális hatás vizsgálatára. A létszámhátrányos játékformációk értékelésére szakcikket a hozzáférhető nemzetközi adatbázisban nem találtunk. Az 1v1, 2v2, 3v3, 4v4 és az 5v5 elleni játékoknál lehet a legtöbb olyan kutatási beszámolót találni, ahol a játékosok pulzusa az anaerob küszöb feletti zónába emelkedik. Mind az 1v1 és 2v2 elleni játékok (Köklü és mtsai, 2011, 2012, 2013; Owen és mtsai, 2004, 2011) mind pedig a 3v3, 4v4 létszámú játékok (Dellal és mtsai, 2008, 2011, 2012; Duarte és mtsai, 2009; Little és mtsai, 2006, 2007, 2009, 2011; Brandes, 2011; Sampaio és mtsai, 2009; Hill-Haas és mtsai, 2009, Fanchini és mtsai, 2010; Duarte és mtsai, 2009, Katis és mtsai, 2009; Da Silva és mtsai, 2011; Rampini és mtsai, 2006; Castelliano és mtsai, 2013) keringést érintő terhelése a $\mathrm{HR}_{\max } 88-92,8 \%$-val volt jellemezheto". $\mathrm{Az} 5 \mathrm{v} 5$ elleni kis játékok hasonló keringési reakciót váltottak ki a futballistákból, mint az előző gyakorlatok. A szerzők (Mallo és Navaro, 2008; Manolopulos és mtsai, 2012; Aroso és mtsai, 2004; Aslan, 2013) által leírt edzésjátékokkal jól modellezhető a nagy intenzitású állóképességi edzés. Mindegyik edzésjáték közös szempontja a keringést ért terhelés intenzitása.

A 6v6, 7v7 és 8v8 elleni játékok már jóval kisebb terjedelemben terhelik a szervezetet az anaerob küszöb felett. Katis és mtsai, 2009; Little és mtsai, 2006, 2007, 2009; Rampini és mtsai, 2006; Hill-Haas és mtsai, 2009; Aslan, 2013; Castelliano és mtsai, 2013; Rodriguez-Marroyo, Penia és Villa, 2009; Jones és Drust, 2007. vizsgálatai azt támasztották alá, hogy ezek a létszámú játékok nem emelik a szívfrekvenciát az anaerob küszöb fölé. Mivel a 3v3 elleni játékot elemeztük, ezért kiemeltük azokat a kutatókat és az általuk leírt tapasztalatokat, amelyek ehhez a kis játékhoz kötődnek. Köklü (2012 és 2011) 15, 16 éves játékosoknál két kutatásában a $\mathrm{HR}_{\max } 91 \%$ és $92,8 \%$ volt. Fanchini és mtsai (2010) a HR ${ }_{\max }$ értékét 88,7\%-nél rögzítették. Little és mtsai (2006) szintén magas, $\mathrm{HR}_{\max } 90,6 \%$ értéket rögzítettek. Ezek a kutatások megegyeztek abban, hogy a játékosokra átlagosan $60 \mathrm{~m}^{2}$ vagy annál nagyobb terület jutott. Rampini és mtsai (2006) a játékot kisebb területen szervezték. Itt átlagosan 40 $\mathrm{m}^{2}$ terület jutott egy labdarúgóra. A $\mathrm{HR}_{\max } 87,6 \%$ volt. Ugyan ők a nagyobb területen már növekvő pulzust regisztráltak. Ha a területet 62,5 és $90 \mathrm{~m}^{2}$ re növelték, akkor a $\mathrm{HR}_{\max } 88,6 \%$ és $89,6 \%$ volt. Owen és mtsai (2011) profi labdarúgóknál $\mathrm{HR}_{\max }$ 91\% eredményt mértek. Dellal és mtsai (2011) profi labdarúgóknál $\mathrm{HR}_{\max } 90 \%$ értéket mértek. Ezekből a mérési eredményekből azt a következtetést lehet levonni, hogy a 3v3 elleni kisjáték alkalmas az anaerob küszöb felett végzett edzésre.

\section{Módszerek}

2015-ben 22 felnőtt játékos, tizennégy hétig, hetente két alkalommal végzett 3v3 elleni edzésjátékot. A játék területe 30×20 méteres volt. A játékot két kiskapura $(1 \mathrm{mx} 2 \mathrm{~m})$ játszották. A kapuk az alapvonal felé fordítva, attól 5-5 méterre helyezkedtek el. Így gólt csak az alapvonal irányából lehetett löni. Az első héten $3 \times 3$ percig végezték ezt az edzést, 2 perc restituciós idővel. A tizennegyedik héten már $8 \times 3$ percig emelkedett a terhelés. A restituciós idő állandó maradt. Minden héten két alkalommal végezte a csapat ezt az edzést. A hét első edzésnapján volt az első edzés és a harmadik napon a következő kis játék terhelés. Kivéve, amikor a hét közepén kupamérkőzést játszottak. A tizennégy hét alatt két kupamérkőzést játszott hétköznap a csapat. Ilyenkor a hét első edzésén $3 \times 3$ perces terhelést alkalmaztunk. A játékosok teljesítményét Yoyo Intermittent Recovery Level 2 (Yoyo IR2) teszttel ellenőriztük.

A kérdéses időszakban a játékosok egészségesek voltak, sérülés, betegség nem nehezítette a munkát. A csapat a tervezett edzésprogramot végre tudta hajtani.

\section{Eredmények}

$\mathrm{Az}$ első héten állóképességi tesztet végeztek a játékosok. A Yoyo IR2 tesztben ekkor a csapat 
átlagos teljesítménye 1255 méter volt. A tizennegyedik héten 1864 méternyi teljesítményt értek el a játékosok.

A teszt $13 \mathrm{~km} / \mathrm{h}$ sebességgel kezdődik, folyamatos terhelésemelkedés mellett, és teljes kimerülésig tart. A teszt során 40 méteres szakaszokban kell futni, majd ezt követi a 10 másodpercnyi aktív pihenési szakasz. A teszteredmények alapján megállapítható, hogy az állóképesség hatékonyan fejlödött. A képesség fejlesztésének céljából alkalmazott 3v3 elleni kisjáték alkalmas az állóképesség fejlesztésére.

Az edzésen mértük a játékosok pulzusát (Polar RS 400), ez alapján terveztük az edzésterhelést, szem előtt tartva a kitűzött edzéscélt.

\section{Megbeszélés}

A játék során igyekeztünk tartani a programban előzetesen leírtakat. Azt terveztük, hogy kéthetente 3 perccel növeljük a játékidőt. A játék terhelés nyílt jellegéből adódóan azonban változtatni kellett az edzések menetén. A kezdeti célkitüzés az volt, hogy a kis játék alatt a pulzus emelkedjen a $\mathrm{HR}_{\max } 90 \%$ a fölé. Ez a kezdeti időszakban meg is valósult. A tapasztalatok szerint a 3 perces terhelés 2 ., 3. percében érte el a keringés a kívánt zónát. Ez meg is felelt az elvárásainknak.

Néhány hét elteltével viszont a pulzus a kívánt szintet már nem érte el. Az edzésen rögzített videó felvételek alapján úgy ítéltük meg, hogy a játék sebessége nem csökkent. Az átadások száma nem csökkent, a technikai végrehajtás minősége is állandó maradt. Úgy véltük, mivel pozitív irányba változhatott a játékosok edzettsége, az adott játékterület és a játék szabályai, már nem váltották ki az elvárt edzéshatást. A terhelés további növelése érdekében a szabályokat módosítottuk. Ezáltal folyamatosabb lett a játék és fokozódott a fizikai igénybevétel. Így a pulzus újra a megfelelő szintre emelkedett.

Összességében megállapítható, hogy az alkalmazott 3v3 elleni játék elérte a célját. Az állóképesség szintje megfelelő mértékben fejlödött. A Dellal és Little által publikált $>\mathrm{HR}_{\max } 90 \%$ értékeket több alkalommal is sikerült elérni.

A publikációk nem tértek ki a progresszivitás kérdésére. Fontos megjegyezni, hogy minden edzésmódszernél lényeges a folyamatos fejlődés fenntartása. Az állandó terheléssel szervezett edzés egy idő után a teljesítmény stagnálásával, majd annak romlásával jár. A játékon belüli fejlesztés egyik alapja a terhelés különböző összetevőinek folyamatos nehezítése. A terület, a létszám változtatása, a szabályok adekvát változtatása a hosszú ideig fenntartható képességfejlődés alapját jelentik.

A játék, mint állóképesség fejlesztő módszer egyszerre több célt is magában hordozhat. A már ismert technikai elemek rögzítését, a taktikai feladatok gyakorlását, valamint az állóképesség edzését is. Ahhoz, hogy mindhárom cél egyszerre megvalósuljon egy folyamatos edzéskontroll és az így szerzett adatok értékelése szükséges. A játékkészség, a technikai szint fejlődésének következménye a kisebb erőkifejtés a játék során.

Bucheit (2010) kutatásai rámutattak még egy másik fontos szempontra is. Ö a nagy intenzitású állóképességi teljesítmény kapcsolatát vizsgálta más kondicionális képességekkel egyetemben. Azt mutatta ki, hogy mind a gyorsaság és az erő, mind pedig a laktát küszöb magas edzettségi szintje szoros kapcsolatban áll a nagy intenzitással végzett szakaszos munkavégzés során produkált teljesítménnyel. Bár Bucheit csak a kondicionális képességek közötti korrelációt vizsgálta, érdemes kapcsolatot keresni az általa vizsgált eredmények és a játékok között is.

A kis játék, mint állóképességi edzésmódszer részleges hatást fejt ki a labdarúgó kondíciójára. A teljes felkészülésnek részét kell, hogy képezze a többi kondicionális képesség fejlesztése is.

Felmerül a technikai-taktikai elemek kis játék formában történő megjelenésekor ezek pontosságának és gyorsaságának kérdése is. A fáradság fokozódásával párhuzamosan csökken a gyors munkavégzés aránya és a finomkoordinációs megnyilvánulások végrehajtásának minősége is gyengül. Így előfordulhat, hogy a kialakuló túlterhelés hatására a komplex edzéshatás céljával megtervezett edzés koordinációs és kognitív elemei nem fejlődnek.

A kis játék, mint nagy intenzitású edzésgyakorlat alkalmas az állóképesség fejlesztésére. A keringési rendszerre gyakorolt hatása megegyezik a futófeladatok által kiváltott edzéseredményekkel (Dellal, 2010).

Ha a pulzus reakciója eléri a kívánt zónát, nincs differencia az edzéseredmények között. Ha a komplex edzéshatás pozitív szempontjait vizsgáljuk, akkor a labdarúgó-specifikus állóképességi teljesítmény hatékonyabb fejlesztője lehet ez az edzésmódszer, mint más hasonló intenzitású, de eltérő mozgásformájú gyakorlat. 


\section{Következtetések}

2015-ben felnőtt labdarúgóknál, 14 héten keresztül alkalmaztuk a 3v3 elleni kisjátékot az állóképesség fejlesztésére. A hetente két alkalommal végzett edzések a játékosok állóképességi teljesítményét jelentősen növelték. A Yoyo IR2 teszt eredményei 1255 méterről 1864 méterre emelkedtek. Az alkalmazott módszer célja az volt, hogy a nagy intenzitású állóképességi edzést komplex, labdarúgásspecifikus formában tudják a futballisták elvégezni.

A játék szervezése során figyelembe kellett venni a progresszivitás elvét is. Ahhoz, hogy az edzés folyamatosan elérje a célját, a játék szabályait a növekvő edzettségi szintnek megfelelően változtatni kellett.

\section{Irodalom}

1. Aslan, A. (2013): Cardiovascular responses, perceived exertion and technical actions during small-sided recreational soccer. Effects of pitch size and number of players. Journal of Human Kinetics, 38: 95-105. http://dx.doi. org/10.2478/hukin-2013-0049

2. Barnes, C., Archer, D.T., Hogg, B., Bush, M. és Bradley, P.S. (2014): The Evolution of Physical and Technical Performance Parameters in the English Premier League. Int J Sports Med. 35: 1-6. http:// dx.doi.org/10.1055/s-0034-1375695

3. Dellal, A., Jannault, R., Lopez-Segovia, M. és Pialoux, V. (2011): Influence of the Numbers of Players in the Heart Rate Responses of Youth Soccer Players Within 2 vs. 2, 3 vs. 3 and 4 vs. 4 Small-sided Games. Journal of Human Kinetics 28: 107-114. http://dx.doi. org/10.2478/v10078-011-0027-8

4. Duarte, R., Batalha, N., Folgado, H. és Sampaio, J. (2009): Effects of exercise duration and number of players in heart rate responses and technical skills during futsal small-sided games. The Open Sports Sciences Journal, 2: 37-41. http://dx.doi. org/10.2174/1875399x00902010037

5. Fanchini, M., Azzlini, A., Castagna, C., Schena, F., Mccall, A. és Impellizzeri, F.M. (2010): Effect of bout duration on exercise intensity and technical perfromance of small sided games in soccer. Journal of Strength and Conditioning Research, 2: 453-458. http:// dx.doi.org/10.1519/jsc.0b013e3181c1f8a2

6. Gibala, M.J., Little, J.P., Essen, M., Wilkin, G.P., Burgomaster, K.A., Safdar, A., Raha, S. és Tarnopolsky, M. (2006): Short term sprint interval vs. traditional endurance training: similar initial adaptations in human skeletal muscle and exercise performance. Physiol., 3: 901-911. http://dx.doi.org/10.1113/ jphysiol.2006.112094

7. Helgerud, J., Hkydal, K., Wang, E., Karlsen, T., Berg, P., Bjerkaas, M., Simonsen, T., Helgesen, C., Hjorth, N., Bach, R. és Hoff, J. (2007): Aerobic high-intensity intervals improve $\mathrm{VO} 2 \max$ more than moderate training. Medicine \& Science in Sport \& Exercise, 4: 665-671. http://dx.doi. org/10.1249/mss.0b013e3180304570

8. Hill-Haas, S.V., Dawson, B., Impellizzeri, F.M és Coutts, A.J. (2011): Physiology of Small-Sided Games Training in Football. Sports Med., 3: 199-220. http://dx.doi. org/10.2165/11539740-000000000-00000

9. Katis, A. és Kellis, E. (2009): Effects of smallsided games on physical conditioning and performance in young soccer players. Journal of Sports Science \& Medicine, 3(8): 374-80.

10. Köklü, Y., Asci, A., Kocak, F.Ü., Alemdaroglu, U. és Dündar, U. (2011): Comparsion of the physiological responses to different smallsided games in elite young soccer players. Journal of Strength and Conditioning Research, 25(6): 1522-1528. http://dx.doi. org/10.1519/jsc.0b013e3181e06ee1

11. Köklü, Y. (2012): A Comparison of physiological responses to various intermittent and continuous small-sided games in young soccer players. Journal of Human Kinetics, 31(2): 89-96. http://dx.doi.org/10.2478/ v10078-012-0009-5

12. Little, T. és Williams, A.G. (2007): Measures of exercise intensity during soccer training drills with professional soccer players. Journal of Strength and Conditioning Research, 21(2): 367-371. http://dx.doi. org/10.1519/00124278-200705000-00013

13. Mallo, J. és Navarro, E. (2008): Physical load imposed on soccer players during small-sided training games. Journal of Sports Medicine and Physical Fitness, 48(2): 166-171.

14. Manolopulos, E., Kalapotharakos, V.I., 
Ziogas, G., Mitrotasios, M., Spaneas, K.S., Savvas, P. és Tokmakidis, S.P. (2012): Heart rate responses durnig small sided soccer games. J Sports Med Doping Stud, 22(2) http:// dx.doi.org/10.4172/2161-0673.1000108

15. Tabata, I., Nishimura, K., Kouzaki, M., Hirai, Y., Ogita, F., Miyachi, M. és Yamamoto, K. (1996): Effects of moderate-intensity endurance and high-intensity intermittent training on anaerobic capacity and VO2max. Medicine and Science in Sports and Exercise, 28(10): 1327-1330. http://dx.doi. org/10.1097/00005768-199610000-00018 